\title{
Türk-İslam Eğitim Geleneğinde Öğretmen-Öğrenci İlişkilerinin Ahlaki Çerçevesi
}

\author{
Mehmet KORKMAZ ${ }^{1}$
}

Öz

Bilim ve teknolojideki gelişmeler her alanı olduğu gibi eğitim alanını da derinden etkilemektedir. Bu gelişmeler sayesinde eğitim ortamları yeniden düzenlenmekte, yeni araç-gereçler kullanılmakta, yeni öğrenme-öğretme kuramları, eğitim modelleri denenmekte, "aktif öğrenme”, “akıllı sınıf”, "sanal sınıf”, “teknoloji destekli eğitim” vb. kavramlar öne çıkarılmaktadır. Bütün bu teknolojik iyileștirmelere ve denemelere rağmen, eğitim süreçlerindeki kalite sorunları tartıșılmaya devam edilmektedir. Yine bugün öğretmen-öğrenci ilişkileri, rolleri, sorumlulukları geçmişe nazaran daha farklı bir boyut kazanmıştır. Buna rağmen, bu ilişkilerin niteliği ve bu ilişkilerin temelinde yer alan değerler dünyasındaki erozyon sıkça sorgulanan hususlardan birisidir. İşte bu sorgulamalarda çağdaş fikirlere ihtiyaç olduğu kadar, uzun ylllar boyunca çeşitli toplum ve devletleri etkilemiş, ancak günümüzde unutulmuş, gerçekte eski(meyen) fikirlerin, değerlerin yeniden hatırlanmasına ihtiyaç vardır. Geniş bir coğrafyada etkili olmuş ve özellikle İslam toplumları üzerinde kalıcı izler bırakmış olan Türk-İslam ilim geleneğinde de bu konuda, sayısız örnekler vardır. İşte bu geleneğin başta gelen temsilcileri olan Selçuklu ve Osmanlı ilim mahfillerinde öğretmen ve öğrencilerin durumu, rolleri, öğretmen ve öğrenci ilişkilerinin ahlaki boyutu konusunda fikir teatisinde bulunmak bugünün eğitimcilerine önemli katkılar sağlayabilir. Bu çerçevede bu çalışmada İslam eğitim geleneğinde öğretmen ve ögrencilerin konumu ve rolleri hakkında özet bir bilgi verilmiş, daha sonra, öğretmenler ve öğrenciler arasındaki ilişkilerin ahlaki boyutu üzerinde durulmuştur. Literatür analizine dayanan çalışmada, Türk-İslam geleneğindeki öncü şahsiyetlerden Farabi, İbn Sina, Maverdi, Yusuf Has Hacib, Gazali, Mevlana, İbn Haldun, Taşköprülü-zâde, Kınalı-zâde gibi alimlerin eserlerinden, onlar hakkında yazılan eserlerden ve eğitim bilimi ile ilgili kaynaklardan yararlanılmıştır.

Anabtar Kelimeler: Türk-İslam Eğitim Geleneği, Eğitim Felsefesi, Öğretmen-Öğrenci İlişkileri

The Moral Frame of the Relationship between Teacher and Student in Turkish-Islamic Educational Tradition

\section{Abstract}

Developments in science and technology have deeply affected the field of education as well as other areas. Owing to these developments, educational environments have been re-organized, new educational tools have been used, new learning and teaching theories and educational models have been tested, and some concepts such as "active learning", "smart classroom,", "technology supported education," have been highlighted today. Despite all of these technological developments and trials, the problems of quality in educational process have been continued to be discussed. Again, relationship between teacher and student, their roles and responsibilities have gained a different dimension comparing with the past, the nature of these relationships and the erosion in the world of values placed on their bases have become one of the issues questioned frequently today. Thus, in this questioning, there is a need for recalling the ideas and values that have influenced various societies and states for a long time in history, but they have been forgotten in our day, indeed, they are not old as well as contemporary thoughts. There are numerous examples about this matter in Turkish-Islamic tradition which have been influential in a wide geographical area and left permanent signs particularly on Islamic societies. The situation of teachers and students, their roles, and the moral dimensions of relationship between teacher and student in the science tradition of Seljuks and Ottoman and discussing those ideas can provide a great contributions today's educators. In this context, this article gives brief information about the position of teacher and student and their roles in the tradition of Islamic education, and then it emphasizes the moral dimensions of relationship between teachers and students.

Key Words: Turkish-Islamic Education Tradition, Philosophy of Education, Teacher and Student Relationships

\section{Atıf İçin / Please Cite As:}

Korkmaz, M. (2020). Türk-İslam eğitim geleneğinde öğretmen-öğrenci ilişkilerinin ahlaki çerçevesi. Manas Sosyal Arasttrmalar Dergisi, 9(1), 529-538.

\footnotetext{
${ }^{1}$ Doç. Dr. - Kırgızistan Türkiye Manas Üniversitesi/Erciyes Üniversitesi, İlahiyat Fakültesi, mkorkmaz@erciyes.edu.tr ORCID ID: 0000-0002-6873-4313
} 


\section{Giriş}

Eğitim tarihi araştırmalarının en temel amacı, geçmişten günümüze kadar olan dönemde çeşitli milletlerin ürettiği, benimsediği, geliştirdiği eğitim ve öğretimle ilgili düşünceleri, kurumlan1, uygulamaları ortaya koymak, insan yetiştirme düzenini ve nasıl bir insan tipi yetiştirilmeye çalışıldığını araştırmak ve bugünkü eğitim sorunlarını daha iyi analiz ederek daha sağlıklı, işe yarar çözüm önerileri bulabilmektir (Akyüz, 2012). Bu biraz da geçmişten ders almakla ilgilidir. Elbette geçmiş tecrübelerden ders çıkarllip onlardan günümüzde yararlanılması kolay değildir. Bu konuda çok çeşitli güçlükler vardır. Yeterli kaynak olmaması, bazı kaynakların değişebilme ihtimali, dil sorunu, kimi kaynakların çok geniş bir coğrafyaya yayılmış olması, kimi kaynaklardaki öznellik sorunu, tarih araştırmalarının yatay ve dikey boyutta incelenmesinin zor olması bu sorunlardan bazılarıdır (Aydın, 1998, s. 85).

Bu bağlamda çalışmaya başlarken birkaç önemli hatırlatmakta fayda vardır. Hiç şüphesiz, bu çalışmanın ismi oldukça geniş bir çağrışıma sahiptir. Zira Türk-İslam geleneği derken, çok geniş bir zaman dilimi ve coğrafya akla gelmektedir. Bu genişlikte ve derinlikteki tarihi süreci bir makalede ortaya koymanın pek çok güçlüğü ve sınırlılı̆ı vardır. Türklerin daha önceleri çoğunlukla göçebe hayat sürmeleri, yazılı kültürün azlığı, hakimiyet mücadeleleri, göçler vb. faktörler İslam öncesi döneme ilişkin kaynaklarımızı daha bir sınırlı kılmaktadır. Nitekim ilgili literatüre bakıldığında da bahsi geçen dönemlere ilişkin olarak yazılıp çizilenlerin oldukça az olduğu görülmektedir. Dolayısıyla genelde bu konudaki bilgiler Karahanlılar devrinden sonraya aittir. İkinci olarak, konuya İslam'dan sonrası için bakıldığında da, Karahanlılar, Gazneliler, Selçuklulular, Harzemşahlar, Eyyubiler, Fatımiler, Memlükler, Osmanlılar gibi devletler akla gelmektedir. Bunların her birinin eğitim uygulamalarını ayrı ayıı çalışmak bile hacimli ansiklopedilerin konusudur.

Betimsel bir özellik taşıyan bu sınırlı çalışmada, bazı meşhur alimlerin görüşlerinden hareketle, ana hatlarıyla, Türk- İslam eğitim geleneğinde öğretmen ve öğrenci kavramlarına yüklenen anlamlar, öğretmen ve öğrencilerin nitelikleri ve öğretmen ve öğrenci ilişkilerinin dayandığı ahlaki ilkeler ana hatlarıyla ortaya konmaya çalışılmışır. Dolayısıyla çalışma temelde literatür taramasına dayanmaktadır. Çalışmada ana hatları ile İslamiyet öncesi ve sonrası dönemlere ilişkin kısa bir giriş yapıldıktan sonra, temel konu olan öğretmen ve öğrenci rolleri, ilişkileri ve bu ilişkilerin dayandığı temel ahlaki ilkeler hakkında bilgi verilmiştir.

Küreselleşme, teknolojik dönüşüm ve açı toplumun getirdiği yeni imkân ve tehditler bağlamında, öğretmen-öğrenci rollerinin, ilişkilerinin, okulla ilgili değerlerin yeniden tartışıldığı bu dönemde söz konusu çalısmanın alana, özellikle de öğretmen ve öğrencilere katkı sağlayacağı umulmaktadır.

\section{İslamiyet Öncesi Dönemde Eğitim Uygulamaları}

İslamiyet öncesi Türklerde halkların genel bilgi ve kültürleri doğrultusunda geliştirdikleri kültür ve bu kültürün örf, adet ve ahlaka yansıyan kısmı olan "töre" son derece önemlidir. Bu töre aynı zamanda eğitimin içeriği, amac1, bunu kimlerin vermesi gerektiği gibi hususlar da içermekteydi. Bu çerçevede, hayvancılık, ziraat, savaş sanatı, sözlü kültür, şïrler, gelenekler, bazı el sanatları ve meslek eğitimi önemsenmektedir. Çocuklara, bilgeliği, yiğitliği, ahlaklllığ öğretmek temel amaçlardandır. Düzenli okulların olup olmadığına ilişkin bilgilerimiz yoktur. Bununla birlikte, bu eğitimin atalardan, hocalardan, ustalardan birebir, yaparak-yaşayarak öğrenildiği ayrıca, yönetici kesimin çocuklarının eğitimine özel bir gayret harcandığı bilinmektedir (Akyüz, 2012, s.5). Bu toplumda erkek çocuklanı yetiştirmek babanın, kız çocukları yetiştirmek ananın görevi kabul edilirdi. Diğer taraftan, "şaman" ya da "kam", denilen kişiler din adamı, kâhin, saz şairi, kâtip, öğretmen anlamlarına da gelmekte ve çeşitli konularda halka önderlik yapmakta, bir tür yaygın eğitim faaliyeti de yapmaktaydılar (Akyüz, 2012, s.10). Hiç şüphesiz bu kişilerin toplumda ayrıcalıklı bir yeri vardı. Dolayısıyla, halka yol göstereme konumunda olan "şaman” ya da "kam"lar sözü dinlenmesi gereken kişiler olarak öne çıkıyordu. Hunlar'da ve Göktürkler'de durum böyleyken, Uygurlar'la birlikte, yerleşik hayata daha çok geçildiği, okul, ibadethane, kütüphane gibi yapıların inşa edildiği, matbaanın gelişimiyle, kitapların çoğaldığı ve eğitimde belli bir birikim ve kurumsallaşma sağlandığ1 bilinmektedir. Bunun bir sonucu olarak, belli bir birikim sağlayan kültürlü Uygurların Türk ve yabancı devletlerin saraylarında kâtiplik, bürokratlık, danışmanlık, tercümanlık, öğretmenlik yapabilecek düzeye geldikleri ifade edilmektedir (Özkan, 2008, s. 15-18). Uygurların Çinlilerden öğrendikleri kâğıt ve matbaa kullanma teknikleri buradan Müslüman Araplara oradan da Avrupalılara ulaşmıştır. Uygurlar kültür, sanat, mimari vb. birçok alanda gelişmişler ancak, Maniheizm dinini benimsedikten sonra, askeri eğitim zayıflamış ve savaşçı kimliklerini kaybetmeye başlamışlardır. Zamanla da güçlerini yitirmişlerdir (Hali ve Rencüzoğulları, 2017, s. 413). 
Türklerin İslamiyet'le tanışmaları ve 751 yılında yapılan Talas savaşının sonuçları Türk coğrafyasında ilim ve kültür bakımından yeni bir döneme kapı aralamıştır. Böylece, Maveraünnehir havzası başta olmak üzere, yeni kurulan şehirlerde (Taşkent, Buhara, Semerkant vb.) Türk- İslam medeniyetinin nişanesi olan ilim kurumları inşa edilmeye başlanmıştır (Taşağıl, 2010, s. 501). Aşağıda bu konuda daha detaylı bilgiler mevcuttur

\section{İslamiyet Sonrası Dönemde Eğitim Uygulamaları}

İslam dinin inzalinden sonra, yeni bir döneme girilmiştir. Bir hadisinde "Ben muallim olarak gönderildim” (İbn Mace, Sünen, 17/I, 83) buyuran İslam peygamberi Hz. Muhammed (sav) kendisine gelen vahiyleri önce yakın çevresine, sonra etraftaki tüm insanlara tebliğ etmeye başlamıs, onun önderliğinde eğitim faaliyeti yeni bir boyut kazanmıştır (Aydın, 2001, s. 62).

"Yaratan Rabbinin Adıyla oku" (Alak/1) ve "Hiç bilenlerle bilmeyenler bir olur mu?" (Zümer/9), ayetlerinde vurgulandığ1 gibi, İslam dinin kutsal kitabı olan Kur'an-1 Kerim’in pek çok yerde ilmi, öğrenmeyi, araştırmayı, düşünmeyi teşvik etmesi ve bu kitabın tebliğcisi olan Hz. Muhammed (sav)'in eğitim uygulamaları Müslümanları da derinden etkilemiş, neredeyse tüm toplum ilmi öğrenme ve öğretme seferberliğine girmişlerdir. Medine'ye hicretten sonra, Onun (sav) özellikle Mescid-i Nebi”yi inşa etmesi ve burada "suffa" adlı bir eğitim kurumu oluşturması, burada hem halkı hem de özel olarak bazı eğiticileri yetiştirmesi, sonraki devirlerde yaşayan Müslüman toplumlar için pusula görevi görmüştür. Bu süreçte İslam eğitim uygulamaları da kurumsallaşmaya başlamıştır.

Fethedilen bölgelerde inşa edilen mescit ve camilerde mutlaka ilim halkaları teşkil edilmiş, buralarda devrin en önemli alim ve talebeleri kendi ilim meclislerini oluşturmuşlardır. Bu ilim halkaları İslam ilim geleneği açısından son derece önemlidir. Zira daha sonraları "İslam ilimleri" diye tabir olunan ilim dalları ve bunların usulleri bu halkalarda teşekkül etmeye başlamıştır. Ayrıca sonraki devirlerde asırlarca tedris edilecek temel kitaplar da bu devirde yazılmaya başlanmışır. Aynı zamanda bu halkalar ameli ve itikadi mezheplerin oluşumuna da zemin hazırlamıştır. Mescitlerde halkalar o kadar artmıştır ki, zamanla buralarda öğrencilerin kalabileceği zaviyeler de eklenmeye başlamış, böylece yatıll medrese işlevi de gören mescitler teşekkül etmeye başlamıştır (Çelebi, 1998).

Daha önce varlığı kabul edilen ve çocuklara eğitim verilen "küttap"lar program ve süreç bakımından yeni bir forma dönüşürken, Mescid'i Nebi ve burada inşa edilen suffa, sonra inşa edilen mescitlerin (cami) İslam dünyasında sadece ibadet mekânı olarak değil, aynı zamanda ilim ve eğitim merkezi olarak öne çıkmasına ve asırlarca bir eğitim kurumu olarak işlev görmesine imkan sağlamıştır. Abbasiler devrinde ilk örnekleri görülen "Beyt'ül Hikme" ve "Dâr'ul ilim" gibi kurumlar başka millet ve kültürlerden getirilen kitapların çevrildiği, yeniden yorumlandığı ve İslam kültür ve medeniyetine kazandırıldığı yerler olmuştur (Dağ, Öymen, 1974). Böylece İslam dünyasında zengin bir ilmi birikim sağlanmış, pek çok tarihçinin yaygın kabulüne göre, Avrupa karanlık çağını yaşarken, İslam dünyası ilimde, kültürde, sanatta, teknikte altın çağını yaşamıştır.

İlk örnekleri Karahanlılar devrinde görülmeye başlanan, ünlü Selçuklu veziri Nizam'ül Mülk’le sistemli ve yaygin hale gelen medreseler ise ilmi faaliyetin en sistemli yapıldığ yerler olmuştur. Bu kurumlar gerek mescitlerin gerekse "Beyt'ül Hikme" ve "Dâr’ul ilim" gibi kurumların bazı işlevlerini devralmışlardır. Böylece hocaların ve talebelerin düzenli olarak kalabilecekleri ve sadece ilimle meşgul olabilecekleri, yatılı ve gündüzlü eğitim kurumlan teşekkül etmiş, bu kurumlar asırlar boyunca tüm İslam coğrafyasına yayılmakla kalmamış, Batıdaki kimi eğitim kurumlarına da örneklik etmişlerdir.

\section{İslam Eğitim Geleneğinde Öğretmenler}

"İlim öğrenmek kadın, erkek her farzdır” (İbn Mace, Mukaddime/17). Hadisini temel bir yaşam ilkesi olarak gören Müslümanlar hemen her yer ve zamanda eğitime büyük bir önem vermişler, bireyin ve toplumun 1slahı için eğitimi çok önemli bir sorumluluk olarak algılamışlardır. Bununla birlikte, öğretmenlik bir taraftan bilgisi ve becerisi olan herkesin gönüllü ve dini bir yükümlülük olarak yaptığı bir vazife iken, diğer taraftan bu görev aynı zamanda başka işlerden ayrılan bir meslek olarak da algılanmıştır (Dağ, Öymen, 1974).

İslam eğitim geleneğinde eğitim toplumun ihtiyaçları doğrultusunda insanlara eğitim veren ve çeşitli isimlerle anılan öğretmenler olmuştur. Bunlar, mahiyet itibariyle aynı işi yapmakla birlikte, bilgilerine/niteliklerine, toplum içindeki konularına, eğitim verdikleri kişilere, mekanlara, eğitim verdikleri alanlara göre farklılık göstermiştir. Bunlardan okullarda yaygın olarak kullanılanlar; múallim, müeddib, 
müderristir. Bunların dişında eğitim verdikleri ihtisas alanlarına göre, fakih, kassas, şeyh, müktib (mükettip), kurrâ vb; hocalığa yükselme sürecinde, yardımcı eğiticiler olarak, kalfa (halife), muî̂d (asistan), müfid; hoca olduktan sonra sayg1 ve taltif amaciyla, üstad, âlim, molla, hoca vb. kavramlar kullanılagelmiştir (Çelebi, 1998, s. 172; Dă̆, Öymen, 1974, s. 196-200; Aydın, 2001, s. 11; Aydın, 2016, s. 460).

Çocuklara, okuma-yazma, hesap, Kur'an okuma, temel dini bilgiler gibi konularda temel bilgilerin verildiği Küttaplarda öğretmenlik yapan eğiticilere "muallim” denilmiştir. Muallimler sosyal itibar, ekonomik imkân, ilmi nitelik bakımından daha düşük profilli kişiler olmuşlardır. Emeviler ve Abbasilerden itibaren yöneticiler, zenginler gibi seçkin zümre çocuklarına özel hocalar tutmaya başlamışlardır (Çelebi, 1998, s. 177). İşte, bu zümrenin çocuklarına belli uzmanlık alanlarında, daha üst düzey bilgi ve beceri eğitimi veren, onların eğitim ve gelişim sorumluluğunu üstlenen öğretmenlere ise "müeddib" denilmiştir. Muallimliğe göre, oldukça itibarlı olan Müeddiplik sonraki devirlerde de varlı̆̆ını sürdürmüş, hatta "atabey"lik, ve "lalalık" gibi kurumların ortaya çıkmasına zemin hazırlamıştır.

Camilerin aynı zamanda bir eğitim mekanı olması hasebiyle, buralarda “meclis'ül ilim” denilen halkalar oluşmaya başlamıştır. İşte bu halkalarda daha üst düzey ilimleri tedris eden öğretmenlere "müderris" denilmeye başlamıştır. Aynı zamanda alim kişilikleriyle öne çıkan bu öğretmenler, pek çok ilmin ve aynı zamanda fikıh, kelam, tefsir, hadis vb. alanlarda ekollerin oluşmasına kaynaklık etmişlerdir. Selçuklular devrinde medreselerin İslam dünyasında öne çıkmaya başlamasıyla birlikte, bu kurumlarda öğretmenlik görevinin üstlenen kişilere de "ders veren" anlaminda, "müderris" denilmeye başlanmıştır (Baltac1, 1976, s. 26). Müderrislik Osmanlı döneminde de en itibarlı mesleklerden olmuştur. Müderrisliğe başlama, görevde yükselme vb. kriterleri hep var olmuştur. İsmi müderris olsa da bunlar ilmi niteliği ve görev yaptığ1 medresenin düzeyine göre, ücretler alabilmişlerdir. Gerek medrese talebesi gerekse medresenin kendisi için müderrisin kim ve ilmi niteliğinin ne olduğu her zaman önemli olmuştur. Zira bir öğrencinin hangi medreseden mezun olduğuna değil, müderrislerinin kim olduğuna ya da başka bir ifadeyle hangi müderrislerden icazet aldığına itibar edilmiştir (Unan, 2005). Bundan dolay1 İslami gelenekte, talebeler için hoca/müderris seçmek daha bir önemsenmiştir. Şunu da hatırlatmak gerekir ki, İslâm eğitim geleneğinde medresede eğitim gören talebelerden yetenekli olanlar, aynı zamanda daha öğrenciyken, hocalık deneyimini de yaşamaya başlamaktaydılar. Bunlar müderrislere eğitim sürecinde yardımcılık yapıp, dersleri arkadaşlarına müzakere, takrir ve tahlil ettiklerinden, hoca yardımcısı, asistan anlamında "mu'id" ismiyle anılıyorlard1. Gerek mu’idler gerekse müderris olmayı düşünen medrese mezunları, mülazemet denilen siteme göre, belli şartları sağlamak koşuluyla müderrisliğe geçirilirlerdi. Müderrisler, hocalık yapmanın yanında isterlerse meşhur âlimlerin derslerine devam ederlerdi. Bu da ilim yolculuğu ve öğrenme konusunda öğrenci ile müderris arasında kesin bir ayrımın olmadığını ve müderrislerin hayatları boyunca ilim öğrenmeye yani talebeliğe devam ettiklerini gösteren dikkat çekici bir husustur.

\section{İslam Eğitim Geleneğinde Öğrenciler}

İslam eğitim geleneğinde öğrenciye, genellikle, "tâlib el-ilm” tamlamasının kısaltılmış şekli olan "talebe" denilmiştir. Bu kelime Arapçada , "ilim talep eden, ilim arayan”, bunun için cehd ve gayret eden kimse anlamına gelmektedir. Dolayısıyla bu kelimenin zengin bir anlamı vardır ve bu haliyle Türkçe'deki "öğrenci" kelimesi ve Arapçadaki “tilmiz" kelimesi tam olarak "talebe” kelimesinin karş1lığ1 değildir. Bunların dışında ilme yeni başlayanlar için “el- mübtedi”, orta-üst düzeyde öğrenim alan bir öğrenciye "el müfîd” ve daha yüksek dereceden bir öğrenime yönelen kimseye de "el- müntehi” dendiği bilinmektedir (Dağ-Öymen, 1974, s. 218).

İslam eğitim geleneğinde bir Müslümanın ilim serüveni aslında hiç bitmemektedir. Beşikten mezara kadar devam etmektedir. Bununla birlikte, bir çocuk genelde Anne-babasından hayata, dine ve ahlaka dair ilk bilgilerini almakta, sonra yaşı 4-5 civarına geldiğinde mahalledeki mektebe gitmekte (ki genelde bunlar cami ya da ona bitişik bir yerdir), burada muallimlerden hesap, Kur'an, temel dini bilgiler, okuma-yazma gibi bilgiler öğrenmekte, sonra eğer yetenekli ise hocasının teşvik ve yönlendirmesi ile ilim yolculuğuna devam etmektedir. Bu da ya bir bilgin ya da şeyhin/alimin halkasina girme, ya "rihle" denilen ilim yolculuğuna çıkma, ya da yakınlarda bulunan ilim ve edep meclislerine katılma şeklinde olmaktadır. Bunların içinde en meşakkatli ve meşhur olanı ilim yolcuğuna çıkmadır. Henüz İslâm'ın ilk yıllarında birçok sahabe ilim yolcuğuna çıkmış, kimiler İslam’ı yaymak, kimileri gittikleri yerlerde yeni ilimleri öğrenmek için uzak diyarlara gitmişlerdir. Örneğin, Abdullah b. Ömer Medine'de, Abdullah b. Abbâs Mekke'de, Mu'âz b. Cebel Yemen'de, Ebû Musa el-Eş‘arî Basra'da, Abdullah b. Mes'ûd Kûfe'de, Abdullah b. es-Sâmit ve Ebû ed-Derdâ Suriye'de, Abdullah b. Amr b. el-As Misır'da ders vermişlerdir (Aydın, 2001, 
s.62). Sonraki devirlerde de sadece hadisleri derlemek için değil aynı zamanda başka milletlerin dillerini, bilgilerini öğrenmek gayesiyle de Müslüman alimler, talebeler uzak ülkelere seyahatler gerçekleştirmişler, adeta "balla yüklü arllar" gibi memleketlerine dönmüşlerdir (Çelebi,1996, s. 181).

İslam eğitim geleneğinde ilim yolcuları olan hoca ve talebelere pek çok imkân sağlanmıştır. Kalacak yer, giyecek elbise, yiyecek yemek, okuma-yazma için kitap, defte, kalem-mürekkep hatta burs bu imkânlardan bazılarıdır. Dolayısıyla öğrenciler yerine göre, bazen mescitlerde, bazen zaviyelerde bazen medreselerde, bazen bir alimin evinde kendileri gibi talebe olan arkadaşlanı ve hocaları ile kalabilmişlerdir. Durum böyle olunca bütün bu imkânlardan yararlanmanın ve birlikte yaşamanın gerektirdiği talepler, nitelikler ve ahlaki bir takım ilkeler de her daim var olagelmiştir. Çalışmanın bundan sonraki kısmında bu konulara ilişkin bilgiler ortaya konacaktır.

\section{İslam Eğitim Geleneğinde Öğretmenlerin Nitelikleri ve Öğrencilerle İlişkileri}

Öğretmenlik peygamberlerin mesleğidir. Aynı zamanda bu gelenekte, öğretmenlere peygamberlerin varisleri olarak bakılır. Dolayısıyla, genelde tüm peygamberlerin özelde Hz. Peygamberin tebliğ ve eğitim misyonunu sürdüren öğretmenlerin bu konumun farkında olmaları, ilmin şerefini korumaları ve bir takım niteliklere sahip olmaları hep vurgulanmıştır (Aydın, 2016, s. 466-467). İslam eğitim klasiklerinde öğretmenlerin sahip olmaları gereken niteliklere dair pek çok eser kaleme alınmıştır. Bu eserlerde öne çıkan hususlar en temelde; a) dindarlık; inanç, amel, ahlak, b) ilim/bilgi, c) becerilerle ilgilidir, denebilir. Bir öğretmenin iman esaslarını eksiksiz kabul eden, ibadetlerini hakkıyla gerçekleştiren, Kur'an ve Peygamber ahlakıyla ahlaklanan, konu alanı bilgisi, genel kültür bilgisi, adabı muaşereti ve öğretmenlik bilgi ve becerisiyle donanık olan bir kişi olması talep edilmiştir. Çalısmanın da amacına uygun olarak biz burada konunun ahlaki boyutuna değinmekle yetineceğiz.

İslam ilim literatüründeki eserlerin konuyla ilgili olarak dikkat çektikleri bir husus öğretmenin ilmiyle, yaşantısıyla, ahlakıyla ve davranışlarıyla hem çevresine hem öğrencilerine örnek olmasıdır. Örneğin İbn Sina’ya göre, eğitimci önce kendini eğitmelidir. Çünkü o davranışları ile öğrencisine örnektir. Bunun içinde şahsiyetini (nefsini) tanımalı ve terbiye etmelidir (Dodurgalı, 2016, s. 209-211). Aynı şekilde, ayet ve hadislerde açıkça vurgulandığı gibi, bir Müslümanın ve dahi hocanın iman, amel, ahlak bütünlügüne sahip olması son derece önemlidir. Örneğin, Gazali, "Hocanın bildiği ve öğrettiği ile amel etmesi lâzımdır. İși sözünü yalanlamamalıdır." der. O’na göre, "Mürşid nakkaş, öğrenci ise nakış yeridir. Nakkaş anlattığı bilgileri kendi özüne nakşetmeden öğrenciye de nakş edemez. Diğer bir benzetme ile hoca ağaç, talebe ise gölge gibidir. Ağaç eğri olunca gölgesi de doğru çıkmaz" (Gazali, 1993, s. 139-147).

Öğretmen-öğrenci ilişkilerinde öne çıkarılan hususlardan birisi de ilmin gayesi ile ilgilidir. İslam ilim geleneğinde öğretmen ve öğrenciler aynı yolun yoldaşı ve karındaşı sayılırlar. Onların yöneldikleri yol, en temelde Allah rızasını kazanmaktır. Bu konuda Gazali, şunları söyler: "İlim yolcusuna düşen sâhib-i şeriat Peygamber Efendimiz'e uymaktır. O bir ilmi öğretme karşıllğında ücret istememeli, hatta talebeden mükafat ve dahi teşekkür bile beklememelidir. Ögrettiğini ancak Allah için öğretmeli ve gayesi Allah’u Teâlâ’ya ulaşmak olmalıdır” (Gazâlî, 1993, s. 139-147). Taşköprülü-zâde de alimin/öğretmenin, her daim gözeteceği temel ilkenin ve ilk vazifenin, Allah'ın rızasını kazanmak, onun emir ve nehiylerine uygun yaşamak, ilmi yaymak ve toplumu irşad etmek suretiyle, toplumdaki alimlerin artmas1, cahillerin, sefihlerin azalması için çaba sarf etmek olduğunu vurgular (Korkmaz, 2016, s. 563). Bunun açllımı olarak dile getirilen hususlar ise gerek öğretmenin gerekse öğrencilerin makam, mevki, para kazanma, şan, şeref, şöhret elde etme, diploma vb. için değil de sadece ve sadece Allah'ı tanıyarak, başta kendi nefsini sslah edip, ahlaki bakımdan gelişerek ve çevresindeki insanlara faydalı olarak bu yolda kalabilmektir. Dolayısıyla öğretmen ve öğrencileri arasındaki ilişkileri belirleyen ilkelerden birisi geçici, günü birlik, dünyalık menfaatler elde etmek değil, ilimle yükselmek ve yücelmek, çevresindekilerin daha iyi insanlar olmaları, yani toplumun 1slah olması için çaba sarf etmektir. Zira bu anlayışa göre, "bir kişinin eliyle bir insanın kötülüklerden kurtulması, 1slah olup, hayır yoluna girmesi, dünya ve içindeki her şeyden değerlidir”.

Bir başka meşhur İslam eğitimcisi olan Kabisi ise yine diğer alimler gibi, eğitimde öğretmeni baba konumuna oturtur. Temelde sevgi ve şefkati önermekle birlikte, tebessümü, laubaliliği, aşır1 yumuşaklı̆ğ tavsiye etmez. Gerektiğinde hocanın yüzünü ekşitmesinin ve sert bir tavır takınmasının da uygun olacağını belirtir (Akyürek, 2016, s. 146-147). Yine Farabi de, öğretmenin öğrencilerine karşı davranışlarının ne çok sert ne de aşırı yumuşak olmaması gerektĭgini vurgular. O’na göre şiddet, baskı, öğrencinin hocasına karşı kin ve nefret duymasına yol acar. Hocanın aşırı derecede yumuşak davranışları da, öğrencinin onu hafife almasına, şahsına ve bilgisine karşı güveninin sarsılmasına sebep olur (Dam, 2016, s. 67). 
Gazali ve Taşköprülü zade gibi alimlerin dikkat çektikleri bir başka husus da talebenin terbiyesinde izlenecek yolla ilgilidir. Buna göre, öğretmen talebede gördüğ̈ eksiklikleri, kusur ve hataları doğrudan doğruya söyleyerek, onun yüzüne vurarak, tahkir ederek, azarlayarak değil, ima ederek, işaret ederek, kinaye ederek, merhametle ve yumuşaklıkla ifade etmektir. Zira, hataları açıç̧a söylemek, azarlayıp kızmak, tahkir etmek talebenin haya perdesini yırtar. Hata yapan kişiye kötülük yapma cesareti verir. Kendisini görmeyenlerin olduğu yerde aynı kötülükleri yapmaya yöneltebilir (Çelikel, 2016, s. 305; Korkmaz, 2016, s. 595).

İbn Cemaa da öğrenciyle iletişim sürecinde izlenmesi gereken yolla ilgili olarak, şunları söyler: "Sözgelişi, bir öğrenci işaretle, ima ile gerekli mesajı alacaksa, öğretmen herkesin içinde öğrenciyi açıkça uyarmamalıdır. Yine öğretmen, ders sonunda öğrencilerin anlayıp anlamadıklarını ögrenmek istediğinde, "Anladın mi?" sorusuna hiç çekinmeden "evet" veya "hayır" diyebileceğini kesinlikle bildiği öğrenciye böyle sorabilir. Aksi takdirde böyle sormamalı, problem ortaya atarak, bilgiyi yoklamayı tercih etmelidir. Öğrenci ile ilgili bir problem varsa, gerektiğinde hoca öğrencinin evine gitmekten çekinmemelidir. Ancak normal durumlarda bunu yapması pek önerilmez. Zira bu ilmin ve alimin itibarını düşürür (Aydın, 2016, s. 462).

Her ne kadar, Yusuf Has Hacip, Kabisi, Kınalızade gibi kim bilginler, belli kayıtlar ölçüsünde, dayağı bir terbiye aracı gibi görseler de (Kaya, 2016:281-282), pek çok eserde vurgulanan ve adeta temel bir ilke haline gelen bir diğer husus ise, hocanın talebesini kendi evladı gibi görmesi, ona sevgi, şefkat ve merhametle davranmasıdır. "Ta'lîmü'l-Müte'allim” adlı meşhur eserin sahibi Hokand'lı Zernûcî öğretmen nitelikleri arasında bilgili, takva sahibi, güzel ahlak sahibi ve tecrübe sahibi olmanın yanında talebeye sevgi ve şefkat göstermeyi de vurgular (ez- Zernuci, 2011, s. 7-9; Tetik, 2016, s. 319-321). Aynı vurgular, Farabi, İbn Haldun, Mevlana gibi alimlerin fikirlerinde de dikkat çeker. Örneğin, Mevlana'ya göre, öğretmen gönül ehli, yumuşak kalpli, olgunlaştırıcı, aydınlatıcı, yüceltici, sabırlı, affedici olmalıdır (Usta, 2016, s. 399-406). İbni Haldun, dayağın ögrencin ilme ve öğrenmeye karşı istek ve neşesini yok edeceğini, onu tembelliğe, yalancilığa, riyakârlığa ve ikiyüzlülüğe teşvik edeceğini söyler, bu davranışların zamanla öğrencide kötü bir karakter ve ahlak oluşturacağına, hatta iyiliğe değil kötülüğe yönelteceğine dikkate çeker (Köylü, 2016, s. 529).

İslam eğitim geleneğinde hocanın nitelikleri anlatılırken, hoca-öğrenci ilişkisi bağlamına sıkça dile getirilen hususlardan birisi de hocanın öğrencini tanımasıdır. Zira bir hocanın talebesini tanımadan, onun özelliklerini, ilgi, istidat ve beklentileri öğrenmeden ona ders vermesi, zorlu ilim yolculuğunda ona rota çizmesi ve onu ulvi gayelere yükseltmesi mümkün değildir (Aydın, 2016, s. 466-467; Korkmaz, 2016, s. 572). Aynı şekilde, hoca öğrencisin özelliğine göre, program hazırlamalı, onun kaldıramayacağı ilimleri ona öğretmemeli, ilimlerin zahiri manalarını ona öğretmeden gizli taraflarını ona vermemelidir. Gazali’ye göre ögretmen talebenin aklının ermeyeceği veya kalbine usanç getiren yahut aklını çok zorlayan konuları, derste tekrar edip durmamalıdır. Öğretmen sanatında Hz. Peygamberin tavsiye ve davranışlarını esas almalıdır (Çelikel, 2016, s. 303).

\section{İslam Eğitim Geleneğinde Öğrencilerin Nitelikleri ve Öğretmenleri İle İlişkileri}

Daha önce ifade edildiği üzere, aslında öğrenci de öğretmenle aynı yola girmiş, aynı meşakkatleri çekmeye karar vermiş, ilimle yükselmeyi kendine hedef koymuş ilim yolcusudur. Dolayısıyla İslam eğitim literatüründe aslında hoca için söylenenleri çoğu öğrenciler için de geçerlidir.

İslam eğitim geleneğinde pek çok eserde Gazalinin görüşlerine atıf yapıllır. O "İhya” adlı kitabında öğrencide bulunması gereken vasıflar konusunda dikkat çekici bilgiler vermiştir. Buna göre, ilim yoluna girecek olan veya giren talebe her şeyden evvel, kalbini bütün fena davranışlardan ve kötü vasıflardan temizlemelidir (Gazâlî, 1993, s. 125-136). Aynı tespit onun yüzyıllar sonra takipçisi olan Taşköprülü-zade de geçer. Buna göre, "kalp nazargah-1 ilahidir." Dolayısıyla nasıl ki Hz. peygamber köpeklerin olduğu eve melek giremez demişse, manevi anlamda köpeklerin yani kötü huyların davranışların yerleştiği bir kalbe de ilim gibi değerli bir varlık giremez (Korkmaz, 2016, s. 587). Yine bu eserlerde öğrencinin dünya ile, fazla yeme, içme ile alakasını kesmesi, kendisini ilme vermesi istenir. Talebe dünyalık için ilimle uğraşmamalı, ilmin değerini yüceltmeli ve Allah rızası için meşgul olmalıdır.

$\mathrm{Bu}$ gelenekte, talebeye düşen görevlerden birisi de hasebi, nesebi pak, takva ve vera sahibi olduğu aşikar, ilimden başka meşguliyetleri olmayan, hep güzel ve faydalı konuşan, insanlar arasında bütün bu özellikleriyle bilinen meşhur bir üstat (hoca) seçmektir. Zira ilim talebesinin kendisinden önce hocasina bakarlar. Eğer hocasi gerçekten alim bir kişi ise, talebenin de bu konuda bir yetkinliğinin olduğu düşünülür. 
Dolayısıyla, talebe, ilmiyle amil, herkesçe meşhur kabul edilen üstad bulduğunda, kendini onun yönlendirmesine bırakmalı, hastanın doktorunun tedavi usulüne riayet ettiği gibi, talebe de hocasının ilim öğretme usulüne karışmamalıdır. Talebe hocasının yanında toprak gibi olmalı, üzerine ne kadar yağmur yağarsa onu boşa götürmemeli, içine çekmelidir. Bu yolda hocasında hata, kusur aramamalıdır. Onun bir sözünü yanlış görse bile, bunu hayra yormalı, hocasının sözüne uymal, yoluna devam etmelidir. Zira yolda yürüyen kimse, kendisine yol gösteren kişinin hata ettiğini zannetse de gittiği yol doğru ve selamettedir (Korkmaz, 2018, s. 310). Belki de bir süre sonra onun sorun gördüğü bu durum açıklığa kavuşacaktır.

Bu konuda yazılmış eserlerde öğrencinin öğretmenine karşı nasıl davranması gerektiği hususunda da detaylı bilgiler verilir. Örneğin, İbn Cemâa'ya göre "öğrenci, öğretmene son derece sayg1lı olmalı; sayg1 anlayışının gereği olarak onun hoşnutluğunu elde etmeye çalışmalıdır. Hocası için göstereceği zilletin izzet, onu saymanın övünç vesilesi, ona karşı mütevazı olmanın da yükselmek olduğunu bilmelidir. Öğretmenin şefkatli, sevecen, ilgili tutumu karşısında öğrenci şımarıp saygıda kusur anlamına gelecek tutum ve davranış sergilememeli, onun sevecenliğini istismar etmemelidir. Öğrenci, öğretmenine saygısının gereği olarak, onun karşısına tertemiz, giyim kuşamı düzgün çıkmalı; onun huzurunda sesini yükseltmemeli, meclislerde veya yürürken saygısını gösteren biçimde davranışına dikkat etmelidir. Öğretmenine olan saygısı, öğrencinin onunla konuşmasına, hitabına bile yansımalıdır. Ona incelik ve nezaketle hitap etmeli, ona saygiyla bağdaşmayacak sözler söylememelidir. Öğrenci, öğretmenine "sen" diye hitap etmemeli, "Efendim", "Üstadım”, “öğretmenim" gibi saygı ve sevgisini belirten ifadeler kullanmalıdır. Onu kendisinin bulunmadığ1 yerde bile ismiyle değil de, ona saygisını gösteren sözlerle anmalı, giybetinin yapılmasını kabul etmemeli, şayet bunu önleyemezse o meclisten ayrılmalıdır. Öğrenci öğretmenini, daima hayırla anmalı, ona dua etmelidir. Hatta öğrenci, öğretmenine saygisı gereği, onun neslini, akrabalarını ve sevenlerini de gözetmelidir” (Aydın, 2016, s. 469).

Bir başka eğitimci olan Zernuci'ye göre de öğrenci hocasının önünde yürümemeli, hocanın makamında (bugünkü tabirle kürsüde) oturmamalı, hocanın yanında, izin alarak konuşmalı ve sözü gereğinden fazla uzatmamalı, hocasına bıktırıcı sorular sormamalı, onun da dinlenmeye ihtiyacı olduğunu düşünerek istirahat zamanlarında onu rahatsız etmemeli, hocası çıkana kadar onu sabırla beklemelidir (ezZernuci, 2011, s. 10-12). Yine O, İmam Şafî̀'nin hocasının huzurunda iken sesini işitip de rahatsız olur düşüncesiyle kitap sayfalarını dahi yavaş yavaş çevirdiği bilgisini bize aktararak, öğrencinin hocasını bin kere dinlemiş olsa bile, ilk günkü gibi saygılı ve ciddi bir şekilde onun dersini dinlemesi gerektiğini aktarır (ez- Zernûcî, 2011, s. 12).

Büyük düşünür Mevlana da, öğretmen-öğrenci ilişsisin bal ile sütün ilişkisi şeklinde açılkar. Ona göre bal ile sütün birleşiminde, bal nasıl sütün içinde eriyip, orada yeni bir anlam kazanırsa, öğrenci de öğretmeni ile böyle bir ilişki içinde olmalıdır. Mevlânâ, öğretmen öğrenci arasındaki ilişkiyi bir alış verişe benzetir. Buna göre, "Sirke verirsin şeker alırsın; boncuk verirsin inci alırsın; sürme verirsin görüş elde edersin, pek hoştur bu alş̧verişte bulunmak!” Buna göre, öğretmen gerçekleştirdiği eğitim süreci ile öğrencinin değersiz yönlerini bile değere çevirir. Onu yüceltir. Halk nazarında itibarlı hale getirir. $O$, bütün bu süreci peygamberin ahlakını kazandırmak olarak da görür (Usta, 2016, s. 92-93).

İslam ilim geleneğindeki yaygın anlayışa göre, hocaya yapılan saygısızlık ilme ve ilmin sahibi olan Allaha karşı yapılan saygısızlık anlamına gelmektedir. Dolayısıyla hocaya gösterilen saygı, ilme ve dolayısıyla da Allaha sayg1 anlamına gelmektedir. Buna göre, hocasını gücendiren, onun kalbini kıran veya onun gönlüne giremeyen bir öğrenci ondan tam olarak istifade edemez ve ilmin bereketinden mahrum olur.

\section{Sonuç}

Ebeveynlerin ve yetişkinlerin çocuklarını eğittikleri, kendi bilgi, beceri, değer, gelenek ve kültürlerini yeni kuşaklara aktardıkları gerçeği göz önüne alındığında, öğretmenlik ve öğrenciliğin insanlık tarihiyle yaşıt olduğu söylenebilir. Bununla birlikte hemen her toplumda öğretmenlik konusunda daha profesyonel olarak bu mesleği yapanlar da olmuştur. Eski Türklerde de anne-babalar çocuklarını eğitmekle birlikte, "şaman" ya da "kam" denilen ve toplumda bilge sayılan kişilerin bireyleri ve toplumu eğitici rollerinin olduğu bilinmektedir. İslamiyet'in gelmesi ve bu Türklerin bu dinle tanışmasından sonra ise eğitim konusunda önemli gelişmeler yaşanmıştır.

İslam dinin ilmi, öğrenmeyi ve öğretmeyi teşvik etmesi, hatta Müslümanlara bunu farz bir ibadet olarak bildirmesi bu konuda hemen herkesin seferber olmasına zemin hazırlamıştır. Hz. Peygamberin kendini aynı zamanda bir muallim olarak tanımlaması ve bunu hayatında uygulaması, Mescid-i Nebi ve Suffa gibi kurumlarda talebe yetiştirmesi, sonraki devirler için de örneklik teşkil etmiştir. Dolayısıyla 
Müslümanlar da fethettikleri ve yolculuk yaptıkları hemen her yer de mescit ve mektep başta olmak üzere eğitim kurumları inşa etmişler, buralarda ilim halkaları oluşturmuşlardır. Selçuklular devrinde medreselerin kurumsal bir yapı olarak ortaya çıkması ve yaygınlaşması bu geleneğin en önemli ve asırlarca iz bırakan bir halkasinı oluşturmuştur.

İslam eğitim geleneğinde ilim yoluna giren öğretmen ve öğrenciler peygamberlik mesleğini sürdüren, onun yoluna giren ve onun mirasina talip olan kişiler olarak algilanmışlar, dolayısıyla gerek nitelik, gerek yaşantı gerekse birbiriyle ve toplumla ilişkiler bakımından onun ahlakıyla ahlaklanması gereken kişiler olarak algılanmışlardır. Bu anlamda öğretmen ve öğrencilerin sağlam itikatlı, ibadetleri ve ahlakı tam, Allah rrzası gibi ulvi gayelere yönelen ve topluma örnek ve rehber olan kişiler olmaları istenmiştir. Bunun bir gereği olarak, onların öğretmen ve ögrenci ilişkilerinde de bir takım ahlaki ilkelere dikkat etmeleri talep edilmiştir.

Öğretmenlerin talebelerini evladı gibi görmeleri, onları tanımaları, onların yeteneklerine en uygun programı tavsiye etmeleri, onların kişiliklerine sayg1 göstermeleri, onları eğitirken, bağırıp, kızmak, toplum içinde kınamak yerine, sevgi ve merhametle muamele etmeleri, aşırı disiplin, gevşeklik vb.den uzak durmaları bu ilkelerden bazılarıdır. Aynı şekilde öğrencilerin de hocalarını seçerken titiz davranmaları, ancak bu seçimi yaptıktan sonra, hocalarına tam bir sayg1 göstermeleri, her daim ona nezaketle davranmaları, onu hayır dua ile anmaları, derslerine ilk günkü gibi azim ve gayretle çalışmaları, hocalarını bir baba, hatta ondan öte bilerek, onun rehberliğine bağlanmaları bunlardan sadece bazılarıdır.

Sonuç olarak, İslam ilim geleneğinde öğretmen ve öğrenci ilişkilerinin insanı merkeze alan, onun bireyselliğini ve gelişimini önceleyen, en temelde, sayg1 ve sevgi ilkesine dayanan bir felsefeye dayandığ1 savunulabilir. Bu anlamda öğretmen ve öğrenci ilişkilerinin yıprandığı, hatta bu ilişkilerin not, hediye, puan gibi maddi ve şekilsel unsurlardan ibaret kaldığ günümüzde geleneğimizdeki öğretmen ve öğrenci ilişkilerinden öğreneceğimiz ve kendimizi sorgulayacağımız önemli hususların olduğu aşikardır.

\section{Kaynakça}

Akyürek, S. (2016). Kabisi. İçinde M. Köylü ve A. Koç (Edt.), Klasik İslam eğitimcileri. (ss.125-158). İstanbul: Rağbet Yayınlar1.

Akyüz, Y. (2012). Türk eğitim taribi. Ankara: Pegem Akademi Yayınları.

Aydın, M. Ş. (1998). "Eğitim tarihi araştırmaları üzerine notlar", Din Eğitimi Araștırmalar Dergisi, (5), 83-98.

Aydın, M. Ş. (2001). "İslam eğitim geleneğinde öğretmenlik", Erciyes Üniversitesi İlabiyat Fakïltesi Dergisi, (11), 59-74).

Aydın, M. Ş. (2016). İbn Cemaa. , İçinde M. Köylü ve A. Koç (Edt.), Klasile İslam eğitimcileri. (ss.444-471). İstanbul: Rağbet Yayınları.

Baltac1, C. (1976). XV-XVI. asirlarda Osmanl medreseleri. İstanbul: İrfan Matbaası.

Çelebi, A. (1998). İslâm'da eğitim-ögretim taribi (Çev: A. Yardım). İstanbul: Damla Yayınları.

Çelikel, B. (2016). Gazali. İçinde M. Köylü ve A. Koç (Edt.), Klasik İslam eğitimcileri. (ss. 287-300). İstanbul: Rağbet Yayınlar1.

Dağ, M.ve Öymen, R (1974). İslam eğitim taribi. Ankara: MEB Yayınları.

Dam, H. (2016). Farabi. İçinde M. Köylü ve A. Koç (Edt.), Klasik İslam eğitimcileri. (ss. 38-97). İstanbul: Rağbet Yayınlar1.38-97.

Dodurgali, A. (2016). İbn Sina. İçinde M. Köylü ve A. Koç (Edt.), Klasik İslam eğitimcileri. (ss. 209-211). İstanbul: Rağbet Yayınlart.209-211.

El-Gazali, (1993). İhya-i ulumu'd-din. (Trc: A. Arslan). İstanbul: Sentez Yayınları.

Er, H. (2016). Kinalızade Ali Efendi. İçinde M. Köylü ve A. Koç (Edt.), Klasik İslam eğitimcileri. (ss. 605-624). İstanbul: Rağbet Yayınları.

Ez-Zernuci, B. (2011). Talim'ul müteallim. (Çev. Y. V. Yavuz). İstanbul: Feyiz Yayınları.

Hali, S. ve Rencüzoğulları S. (2017). "İslamiyet öncesi dönemde Türklerde eğitim", 21. yüsyylda eğitim ve toplum Dergisi, $6(17), 425-437$.

Kaya, U. (2016). Yusuf Has Hacip. İçinde M. Köylü ve A. Koç (Edt.), Klasik İslam eğitimcileri. (ss. 256-286). İstanbul: Rağbet Yayınları.

Korkmaz, M. (2016). Taşköprülü-zade. İçinde M. Köylü ve A. Koç (Edt.), Klasik İslam eğitimcileri. (ss. 555-604). İstanbul: Rağbet Yayınları.

Korkmaz, M. (2018). "Taşköprülü-zade’ye göre öğretmenlik ve öğrencilik ahlakı” Manas Sosyal Arasstrrmalar Dergisi, 7(3), 297-318.

Köylü, M. (2016). İbn Haldun. İçinde M. Köylü ve A. Koç (Edt.), Klasike İslam eğitimcilerr. (ss. 515-540). İstanbul: Rağbet Yayınları.

Özkan, S. (2008). Türk eğitim taribi. Ankara: Nobel Kitap Dağtım.

Tașağıl, A., (2010). Talas Savaşı. Dijanet İslam ansiklopedisi, İstanbul: Türkiye Diyanet Vakfi Yayınları. (39), 501.

Tetik, H. (2016). Zernuci. İçinde M. Köylü ve A. Koç (Edt.), Klasik İslam eğitimcileri. (ss.319-331). İstanbul: Rağbet Yayınlar1. 
Unan, F. (2005). Klâsik dönem Osmanlı medreselerinde eğitim üzerine yapılmış çalışmalara dair bir bibliyografya denemesi. Dîân İmî Arașturmalar http://yunus.hacettepe.edu.tr/ unan/academicarticles.html (12.09.2018 tarihinde alınd1.)

Usta, M. (2016). Mevlana. İçinde M. Köylü ve A. Koç (Edt.), Klasik İslam eğitimcileri. (ss.381-420). İstanbul: Rağbet Yayınları.

Ünalan, S. ve Öztürk, H. (2008). “İslamiyet’ten önce Türkler' de eğitim ve öğretim”, Furat Üniversitesi İlahiyat Fakültesi Dergisi, 13(2), 89-109.

\section{EXTENDED ABSTRACT}

Developments in science and technology have deeply affected the field of education as well as other areas. Owing to these developments, educational environments have been re-organized, new educational tools have been used, new learning and teaching theories and educational models have been tested, and some concepts such as "active learning", "smart classroom," "technology supported education," have been highlighted today.

Despite all of these technological developments and trials, the problems of quality in educational process have been continued to be discussed. Again, relationship between teacher and student, their roles and responsibilities have gained a different dimension comparing with the past, the nature of these relationships and the erosion in the world of values placed on their bases have become one of these issues questioned frequently today.

For the process of education in general and relationship between teacher and student in particular have been far from an existential form of relationship which are internalized values. The reason of this, means has been replaced by purpose. At this point, we have to query again the process of education such as schools, curriculums, aims, means, methods, environments, the roles of teachers and students.

Thus, in this questioning, there is a need for recalling the ideas and values that have influenced various societies and states for a long time in history, but they have been forgotten in our day, indeed, they have are not old as well as contemporary thoughts. There are numerous examples about this matter in Turkish-Islamic tradition which has been influential in a wide geographical area and left permanent signs particularly on Islamic societies. The situation of teachers and students, their roles, and the moral dimensions of relationship between teacher and student in the science tradition of Seljuks and Ottoman and discussing those ideas can provide a great contributions today's educators.

In this context, this article gives brief information about the position of teacher and student and their roles in the tradition of Islamic education, and then it emphasizes the moral dimensions of relationship between teachers and students.

This paper based on the literature analysis. And we will try to investigate within the framework of the viewes of the scholars such as Farabi, Ibn Sina, Maverdi, Yusuf Has Hacib, Ghazali, Mevlana, Ibn Khaldun, Taşköprülü-zâde, Kinalizade and the some works written about them and basic sources about pedagogy. For example, how they approach to the education (teachers, students, curriculums, aims, methods, environments, etc.), and how they give position to the teacher and student, how they see the relationship between the teacher and student. We'll also will try to understand the principles that they care about and we'll compare these principles with the existing education ethics.

Some of these results of the study as follow: Education of children in Turkish-Islamic educational tradition was accepted as a basic task of parents. However, being teacher and studentship were always seen as a valuable profession and a style of living. For the religion of Islam has accepted teaching and learning as worship. In Islamic educational tradition, both teachers and students were provided many opportunities and facilities such as accommodations, clothing, food, books, notebooks, pen-ink, scholarship and others. The qualifications, duties and roles of teachers and students were explained in detail in the tradition of Turkish-Islamic education. In addition, the ethics of teaching and learning was accepted as a field of basic subject and perceived as a prerequisite condition for obtaining knowledge in this tradition.

In this tradition, both teachers and students were accepted as the heirs of prophets. For it is emphasized that both teachers and students should have good morality, establish honest and intimate relationship with each other, believe in Allah, perform their religious duties and be beneficial for the society. 
In order to achieve this; teachers must first educate themselves and then their students. In addition, teacher should love his student as his own child, recognize him, give value him, practice a program that suits best his physical, spiritual and intellectual development and lastly be a model and guide for his student.

In addition, students should be careful for choosing their teachers, accept them as their fathers, be respectful always for their teachers, pray for them and do their courses as their best. Further, the student should wear clean and well dress, not speak loudly to his teacher and speak just by permission. For according to the tradition of Islamic education, not respecting to teacher means disrespect for knowledge and the true owner of it. Thus, a student who distresses his teacher, breaks his heart or not love his teacher cannot take advantage from his teacher fully and lacks the abundance of learning. 